\title{
PENYELESAIAN SENGKETA WARIS TANAH ADAT PADA MASYARAKAT ADAT KARO
}

\author{
Maria Kaban*
}

Departemen Hukum Perdata, Fakultas Hukum Universitas Sumatera Utara, Jalan Universitas Nomor 4, Kota Medan, Sumatera Utara, 20155

\section{Abstract}

Disputes are inevitable. Disputes can occur in almost all aspects of life. In Karo communities, disputes are generally associated with the object of inheritance. Land as one of the objects of inheritance is considered to have more value in Karo communities. Therefor disputes that occur are usually associated with land ownership. Due to the disputes that happens is still in the realm Karo local law, then Karo customary law and existing national laws should be taken into account.

Keywords: disputes, inheritance, land, local law, karo.

\section{Intisari}

Sengketa merupakan hal yang tidak terelakkan dalam kehidupan bermasyarakat. Sengketa dapat terjadi dalam hampir seluruh aspek kehidupan. Pada masyarakat adat Karo sengketa yang terjadi pada umumnya berkaitan dengan objek waris. Tanah sebagai salah satu objek waris dianggap memiliki nilai "lebih" dalam masayarakat adat Karo. Untuk itu sengketa waris adat yang terjadi biasanya berkaitan dengan kepemilikan tanah. Dikarenakan sengketa waris yang terjadi masih dalam ranah masyarakat adat, maka dalam penyelesaiannya juga tetap memperhatikan hukum adat dan hukum nasional yang ada.

Kata Kunci: sengketa, waris, tanah, adat, karo.

\section{Pokok Muatan}

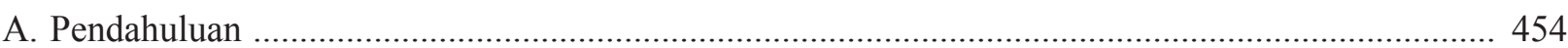

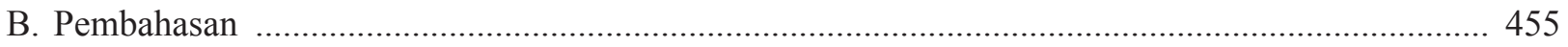

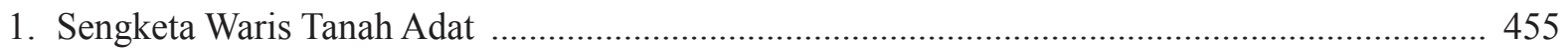

2. Upaya Penyelesaian Sengketa Waris Tanah Adat pada Masyarakat Adat Karo ......................... 457

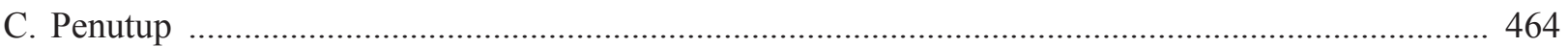




\section{A. Pendahuluan}

Pluralisme hukum waris di Indonesia membuktikan bahwa hingga saat ini belum ada unifikasi hukum waris di Indonesia melainkan masih berlaku hukum waris adat, hukum waris agama Islam dan hukum waris KUHPerdata Eropa. Hal ini merujuk pada peraturan peralihan Pasal 2 UUD 1945 yang memberlakukan peraturan hukum pada zaman Belanda selama belum ada dibentuk peraturan hukum yang baru menurut UUD ini.

Hukum Waris Adat adalah salah satu aspek hukum dalam lingkup permasalahan Hukum Adat yang meliputi norma-norma yang menetapkan harta kekayaan baik yang materiil maupun yang imaterial, yang mana dari seorang tertentu dapat diserahkan kepada keturunannya serta yang sekaligus juga mengatur saat, cara dan proses peralihannya dari harta dimaksud. ${ }^{1}$ Bentuk harta kekayaan materiil dapat berupa tanah, perhiasan, senjata, dan lain-lain, sedangkan bentuk harta kekayaan imaterial dapat berupa nama kebesaran. Dalam masyarakat adat, yang menurut sistem kekerabatannya terdiri atas (1) masyarakat dengan sistem kekerabatan patrilineal, (2) masyarakat dengan sistem kekerabatan matrilineal, (3) masyarakat dengan sistem kekerabatan parental, proses peralihan harta waris berbeda-beda. Seperti pada masyarakat patrilineal, apabila terjadi putus perkawinan karena suami wafat maka istri berkewajiban tetap mengurus semua harta perkawinan yang ditinggalkan beserta anakanaknya. ${ }^{2}$ Sedangkan pada masyarakat parental, jika terjadi putus perkawinan karena suami atau istri wafat maka suami atau istri yang hidup meneruskan tanggung jawabnya sebagai kepala rumah tangga yang mengurus harta perkawinan dan anak-anak dengan memperhatikan adanya pesan ("amanah", "wasiat", Islam; "Weling", Jawa) dari yang wafat ketika hidupnya. ${ }^{3}$ Kemudian pada masyarakat matrilineal, dikenal dengan perkawinan semendo (semenda), yaitu bentuk perkawinan yang bertujuan untuk mempertahankan garis keturunan dari pihak ibu, apabila seorang suami meninggal maka harta pencaharian seorang suami tidak akan diwaris oleh anak-anaknya sendiri melainkan oleh saudarasaudaranya sekandung beserta keturunan saudarasaudara perempuan sekandung. ${ }^{4}$

Penguasaan dan pemilikan atas tanah oleh masyarakat hukum adat, oleh Van Vollenhoven disebut sebagai beschikkingsrecht. Masyarakat hukum adat dalam hal ini berfungsi sebagai pengawas ketertiban dan keamanan penggunaan hak ulayat. Hak penggunaan tanah adat yang diberikan Masyarakat hukum adat dapat memberikan hak kepada anggota masyarakat hukum adat ataupun masyarakat di luar masyarakat hukum adatnya untuk memanfaatkan tanah adat dengan syarat harus mematuhi peraturan ketua adat dan hak-hak komunal yang terdapat dalam tanah adat tersebut. Dengan kata lain hak-hak perseorangan atas tanah adat itu dibatasi oleh hak ulayat. Apabila dikemudian hari bidang tanah tersebut dikerjakan terus menerus oleh warga persekutuannya dan kemudian diberikan tanda pembatasan maka hasil dari tanah tersebut hanya dapat dikuasai oleh warga yang membuka dan mengerjakan tanah tersebut sehingga ia mempunyai hak milik atas tanah tersebut. Apabila warga persekutuan yang mengerjakan tanah itu memutuskan dirinya dari persekutuan hak atas tanah itu akan hilang dan kembali dikuasai oleh persekutuan. Menurut Ter Haar hubungan antara kepentingan perseorangan dan kepentingan persekutuan adalah timbal balik dan mempunyai daya kekuatan yang sama.

Dalam hal tanah adat tersebut telah menjadi hak milik dari warga masyarakat adat maka apabila warga masyarakat tersebut meninggal dunia dengan meninggalkan ahli waris maka hak milik ini dapat diwariskan kepada ahli waris dari si pewaris. Sesuai dengan judul penelitian yang difokuskan pada penyelesaian sengketa waris tanah adat pada

\footnotetext{
Tolib Setiady, 2008, Intisari Hukum Adat Indonesia (Dalam Kajian Kepustakaan), Penerbit Alfabeta, Bandung, hlm. 281 Hilman Hadikusuma, 1990, Hukum Perkawinan Adat, Citra Aditya Bakti, Bandung, hlm. 188.

Ibid., hlm. 188-189.

Tolib Setiady, Op. cit., hlm. 289.
} 
masyarakat adat karo maka penelitian ini dibatasi oleh waris tanah adat pada masyarakat karo yang mempunyai sistem kekerabatan patrilineal (garis keturunan dari pihak bapak).

\section{B. Pembahasan}

\section{Sengketa Waris Tanah Adat}

\section{a. Definisi Sengketa}

Menurut kamus umum Bahasa Indonesia, sengketa adalah pertengkaran; perbantahan, pertikaian; perselisihan; percederaan, dan perkara. $^{5}$ Sedangkan menurut badan arbitrase perdagangan berjangka komoditi, sengketa adalah suatu pertentangan atas kepentingan, tujuan dan/ atau pemahaman antara 2 (dua) pihak atau lebih. Sengketa akan menjadi masalah hukum apabila pertentangan tersebut menimbulkan perebutan hak, pembelaan atau perlawanan terhadap hak yang dilanggar, dan/atau tuntutan terhadap kewajiban atau tanggungjawab.

Sengketa atau penggunaannya dalam bahasa inggris disebut dengan conflict mendapat persepsi ganda oleh kalangan para sarjana. Beberapa sarjana berpendapat bahwa antara sengketa dan conflict memberikan nuansa yang berbeda dalam cara pendefenisiannya. Sengketa dipersamakan dengan dispute dalam bahasa inggris yang mempunyai arti adanya perselisihan atau perbedaan pandangan yang telah diketahui oleh pihak-pihak yang tidak terlibat dalam perselisihan tersebut. Dalam hal pengertian konflik, Nurnaningsih berpendapat:

Sedangkan konflik merupakan perselisihan yang belum diketahui oleh pihak-pihak yang tidak terlibat di dalam perselisihan tersebut dan mencakup perselisihan yang bersifat laten, oleh karena itu konflik mempunyai ruang lingkup yang lebih luas daripada sengketa, namun dalam penggunaannya secara ilmiah, khususnya dalam ruang lingkup penelitian hukum, istilah sengketa (dispute) telah menjadi istilah baku dalam praktik hukum. ${ }^{6}$

Dari beberapa pengertian sengketa yang telah diuraikan di atas maka dapat ditarik kesimpulan bahwa sengketa adalah perselisihan yang terjadi antara dua belah piahk atau lebih yang terakumulasi hingga para pihak yang tidak terlibat dalam perselisihan tersebut mengetahui akan adanya sengketa tersebut.

\section{b. Definisi Waris Adat}

Waris adalah proses beralihnya harta kekayaan dari si pewaris kepada ahli waris. Dalam hukum adat, proses peralihan harta kekayaan ini dapat terjadi pada saat pewaris telah meninggal dunia, ataupun sebelum pewaris meninggal dunia, yang diwariskan adalah harta milik pewaris yang dapat berwujud maupun tidak berwujud. Peralihan harta kekayaan yang terjadi setelah pewaris meninggal dunia disebut wasiat sedangkan peralihan harta kekayaan sebelum pewaris meninggal dunia disebut hibah.

Menurut I Gede A.B Wiranata harta warisan dapat dibagi menjadi beberapa yaitu:

Pertama, Harta warisan adalah harta kekayaan dari pewaris yang telah wafat, baik harta itu telah dibagi atau masih dalam keadaan tidak terbagi-bagi. Istilah ini dipakai untuk membedakan dengan harta yang didapat seseorang bukan dari peninggalan pewaris, melainkan didapat sebagai hasil usaha pencaharian sendiri di dalam ikatan atau di luar ikatan perkawinan. Jadi, warisan atau harta warisan adalah harta kekayaan seseorang yang telah wafat. Kedua, Harta asal adalah semua harta kekayaan yang dikuasai dan dimiliki pewaris sejak mula pertama, baik berupa harta peninggalan ataupun harta bawaan yang dibawa masuk ke dalam perkawinan dan kemungkinan bertambah selama perkawinan. Keti- 
ga, Harta peninggalan adalah harta ini menunjukkan harta warisan yang belum terbagi atau tidak terbagi-bagi disebabkan salah seorang pewaris masih hidup. Misalnya harta peninggalan ayah yang telah wafat yang masih dikuasai ibu yang masih hidup atau sebaliknya harta peninggalan ibu yang telah wafat, tetapi masih dikuasai ayah yang masih hidup. Termasuk di dalamnya ialah harta pusaka. Keempat, Harta pusaka. Harta ini dikategorikan ke dalam harta pusaka tinggi dan harta pusaka rendah. Harta pusaka tinggi berasal dari zaman leluhur, yang disebabkan keadaannya, kedudukannya, sifatnya tidak patut , tidak pantas, dan tidak dapat dibagibagi. Kelima, Harta perkawinan Harta ini menunjukkan semua harta kekayaan yang dikuasai atau dimiliki oleh semua istri disebabkan adanya ikatan perkawinan. $^{7}$

Soepomo merumuskan hukum adat waris adalah sebagai berikut:

Hukum Adat Waris memuat peraturanperaturan yang mengatur proses meneruskan serta meng-over-kan barang-barang harta benda dan barangbarang yang tidak terwujud benda (immaterielle goederen) dari suatu angkatan manusia (generatie) kepada turunannya. (proses itu telah dimulai dalam waktu orangtua masih hidup. Proses tersebut tidak menjadi akut oleh sebab orangtua meninggal dunia). ${ }^{8}$

Sedangkan menurut Bushar Muhammadd menyebutkan sebagai berikut:

Hukum waris adalah serangkaian peraturan yang mengatur penerusan dan peng-over-an harta peninggalan atau harta warisan dari sesuatu generasi ke generasi lain, baik mengenai benda material maupun imaterial. Bahwa hukum waris dimaksud mencakup pula persoalan-persoalan, tindakantindakan mengenai pelimpahan harta benda semasa seseorang masih hidup. Lembaga yang dipakai dalam hal ini ialah Hibah. ${ }^{9}$

Sistem pewarisan hukum adat menganut sistem aliran air, dimana yang pertama kali mendapatkan warisan adalah ahli waris keturunan ke bawah yaitu anak, cucu, dan seterusnya ke bawah (golongan ke-1). Apabila keturunan ke-1 tidak ada (terdinding) maka warisan akan jatuh kepada orang tua pewaris (golongan ke-2). Apabila keturunan golongan ke-1 dan ke-2 terdinding maka warisan akan jatuh pada saudara pewaris beserta keturunannya (golongan ke-3), kemudian dengan terdindingnya ahli waris golongan ke-1, ke-2 dan ke-3 maka warisan akan jatuh kepada golongan ke-4 yaitu kakek dan nenek pewaris.

Unsur penting dalam pewarisan antara lain adanya pewaris, ahli waris dan harta peninggalan, tanpa terpenuhinya salah satu unsur di atas maka, proses pewarisan tidak akan terjadi. Sistem pewarisan adat sangat tergantung dari sistem kekerabatan yang berlaku oleh masing-masing masyarakat adat seperti sistem kekerabatan patrilineal, matrilineal, dan bilateral. Hukum adat waris mengenal adanya tiga sistem kewarisan, yaitu: Pertama, Sistem kewarisan individual, Sistem pewarisan dimana setiap waris mendapatkan pembagian dari harta peninggalan untuk dapat dimiliki menurut bagiannya masing-masing. Sistem kewarisan ini terdapat pada masyarakat jawa, batak, Sulawesi, dan lainnya. Kedua, Sistem kewarisan kolektif. Sistem kewarisan kolektif adalah sistem pewarisan dimana sekelompok ahli waris secara bersama-sama merupakan secara badan hukum, dimana harta tersebut disebut sebagai Harta Pusaka tidak boleh dibagi-bagikan pemiliknya di antara para

I Gede A.B Wiranata, 2005, Hukum Adat Indonesia Perkembangannya dari Masa ke Masa, Citra Aditya Bakti, Bandung, hlm. 20.

Tolib Setiady. Op. cit., hlm. 281

Ibid., hlm. 282. 
ahli waris dimaksud dan hanya boleh dibagibagikan pemakaiannya saja kepada mereka itu seperti dalam masyarakat matrilineal. Ketiga, Sistem kewarisan mayorat. Sistem kewarisan mayoran adalah sistem kewarisan seorang anak menerima warisan berupa sebagian besar atau keseluruhan, sistem kewarisan ini terdapat di Bali dimana terdapat hak mayorat anak laki-laki yang tertua dan di tanah semendo dimana terdapat hak mayorat anak perempuan tertua.

\section{c. Definisi Tanah Adat}

Tanah mempunyai peranan penting bagi masyarakat hukum adat. Tanah adalah tempat tinggal, bercocok tanam, tempat dimana anggota masyarakat adat dikuburkan, serta tanah merupakan tempat tinggalnya makhluk gaib dan roh-roh para leluhur. Di samping itu, tanah juga bersifat tetap dalam artian tidak berubah-ubah meskipun apapun yang terjadi tanah tersebut akan tetap. Dilihat dari lapangan hukum harta kekayaan pun, tanah merupakan harta benda tetap yang dapat diwariskan kepada ahli waris dari si pemilik tanah tersebut.

Berdasarkan penjelasan di atas dapat kita simpulkan bahwa antara masyarakat hukum adat dengan tanah mempunyai keterikatan religio magis yang membuat tanah mempunyai bidang pengaturan sendiri berupa hukum tanah dalam hukum adat. Hubungan yang serta dan bersifat religio magis ini menyebabkan persekutuan memperoleh hak untuk menguasai tanah dimaksud, memanfaatkannya tanah itu, memungut hasil dari tumbuh-tumbuhan dan atau pohon-pohonan yang hidup di atas tanah tersebut serta juga berburu binatang-binatang yang hidup di situ. ${ }^{10}$ Tanah yang dikuasai oleh masyarakat hukum adat disebut juga tanah adat /tanah ulayat/tanah hak pertuanan adalah suatu lingkungan tanah yang hidup dalam kekuasaan masyarakat adat yang sah. ${ }^{11}$ Tanah adat ini dapat berupa kolam, sawah, lahan kosong, hutan, pantai, dan lain-lain.

Pada masyarakat adat pada umumnya terdapat tanah-tanah yang dikuasai oleh masyarakat yang bersangkutan yang diatur menurut hukum adatnya masing-masing. Mengenai masyarakat hukum, Soerjono Soekanto mengemukakan:

Dalam masyarakat Indonesia terdapat persekutuan-persekutuan. Ada persekutuan (dahulu) dimana warganya mempunyai hubungan kekerabatan yang erat dan berdasarkan keturunan satu nenek moyang, ada juga pesekutuan yang tidak berdasar hubungan kekeluargaan, tetapi berdasar daerah atau wilayah yang didiami, dan ada persekutuan yang dasarnya tidak hanya hubungan kekerabatan akan tetapi juga daerah atau wilayah yang didiami. Persekutuan tersebut baik yang pertama maupun yang kedua atau yang ketiga mempunyai warga yang teratur, yang agak tetap, yang mempunyai pemerintahan sendiri (kepala dan pembantunya), mempunyai harta material dan inmaterial sendiri, persekutuan ini adalah dalam suasana rakyat dapat disebut persekutuan hukum. Selanjutnya dalam persekutuan tersebut ada keterikatannya dengan tanah desanya yaitu daerahnya, mengikat kelompok-kelompok yang tinggal disitu dan yang tidak mempunyai hubungan kekeluargaan menjadi suatu persekutuan hukum suatu kesatuan (genelaogis). ${ }^{12}$

\section{Upaya Penyelesaian Sengketa Waris Tanah Adat Pada Masyarakat Adat Karo}

Masyarakat adat Karo merupakan masyarakat hukum yang memiliki sistem hukum adatnya sendiri yang diakui dan dihormati dalam

Tolib Setiady, Ibid., hlm. 312.

Djamanat Samosir, 2013, Hukum Adat Indonesia Eksistensi Dalam Dinamika Perkembangan Hukum di Indonesia, Nuansa Aulia, Bandung, hlm. 103 .

12 Soerjono Soekanto, 1985, Meninjau Hukum Adat Indonesia, Rajawali, Jakarta, hlm. 67. 
sistem pemerintahan Negara Republik Indonesia. Berbicara mengenai masalah berarti berbicara mengenai hukum adat Karo, hal ini disebabkan hubungan yang begitu erat antara masyarakat adat Karo dengan tanahnya. Begitu eratnya hubungan antara tanah dengan masyarakat adat Karo sehingga tanah dalam suku Karo mempunyai aturan mengenai hukum tanah adat dan menjadi salah satu objek waris oleh masyarakat adat Karo.

Dalam masyarakat adat Karo pada umumnya, terdapat pengkategorian terhadap tanah, yakni: Pertama, Taneh kuta (village land), Taneh kuta adalah tanah yang dimiliki oleh desa tertentu sebagai pembeda dari kampung lain, termasuk di dalamnya tanah terbuka, kuburan, dan tanah kosong. ${ }^{13}$ Kedua, Taneh kesain (ward land), Konsep taneh kesain merujuk kepada kawasan perkampungan, sebagai contoh, taneh Rumah Berneh menunjukkan bahwa tanah tersebut milik Kesain Rumah Berneh. Ketiga, Taneh nini (grandfather's land), Konsep taneh nini digunakan untuk tanah yang yang telah ditanami pertama kali oleh bapa (bapak/ayah), nini (kakek), nini nai (leluhur). Tanah ini dipunyai oleh anggota dari garis kekerabatan patrilineal. Kelompok patrilineal dan anggotanya memiliki ikatan yang sakral kepada tanah leluhurnya yang harus dipertahankan dengan tidak melepaskannya kepada orang lain. Tanah seperti ini pada umumnya diwariskan dari ayah kepada anak laki-lakinya, dan untuk kemudian akan selalu berada dalam keluarga atau kelompok kekerabatan patrilineal. ${ }^{14}$ Keempat, Taneh kalimbubu (land of the kalimbubu), ${ }^{15}$ Konsep taneh kalimbubu digunakan untuk tanah yang diberikan oleh kalimbubu kepada anak beru. Pada taneh kalimbubu, kalimbubu harus dilibatkan dalam setiap keputusan yang berkaitan dengan taneh kalimbubu.

Sistem pewarisan dalam masyarakat adat Karo didasarkan pada garis keturunan ayah (patriarchaat). Masyarakat Karo yang menarik garis keturunan dari kebapakan mempunyai karakteristik: (1) Stelsel perkawinan di Karo bersifat eksogami, perkawinan berlainan marga atau di luar marga. Sebabnya secara empiris dapat diterangkan bahwa satu marga dianggap satu keturunan atau satu klan, sehingga perkawinan satu marga tidak diperkenankan. Dari sudut lain stelsel perkawinan tersebut berakibat bahwa si wanita yang kawin telah masuk marga/klan suaminya dan terlepas dari marga/ klan keluarganya semula. Jadi tegasnya perkawinan itu berakibat lepasnya si wanita dari marga/klan ayahnya dan masuk keluarga/klan suaminya. Dan yang lepas itu sebenarnya adalah wanita itu bersama hak dan kewajibannya dari marga/klan orangtuanya sendiri. (2) Persekutuan hukum marga. Hampir seluruh marga di Karo mempunyai persekutuan hukum yang dikepalai oleh "bangsa taneh"/"anak taneh" dari marga itu yaitu "simatek"/mendirikan "kuta"/kampung pada mulanya. ${ }^{16}$

\section{a. Penyelesaian Sengketa Melalui Runggun.}

Pada masa sekarang ini peradilan adat berangsur-angsur hilang, runggun kutal kesain, runggun urung, runggun sibayak, dan runggun sibayak berempat sudah tidak dipakai lagi dalam menyelesaikan masalah. Runggun yang masih dipakai saat ini hanyalah runggun keluarga dan umumnya runggun ini sering dipakai dalam nerehempo ${ }^{17}$, penguburan, pindah rumah, perceraian, penggantian nama, dan juga dalam menyelesaikan masalah. Runggun dalam masyarakat Karo mempunyai makna yang luas tidak hanya digunakan untuk menyelesaikan masalah saja, oleh karena itu tidaklah etis untuk mendefinisikan runggun sebagai lembaga penyelesaian sengketa antar masyarakat adat Karo. Runggun baik dalam kegunaannya sebagai lembaga penyelesaian masalah maupun dalam kegunaannya yang

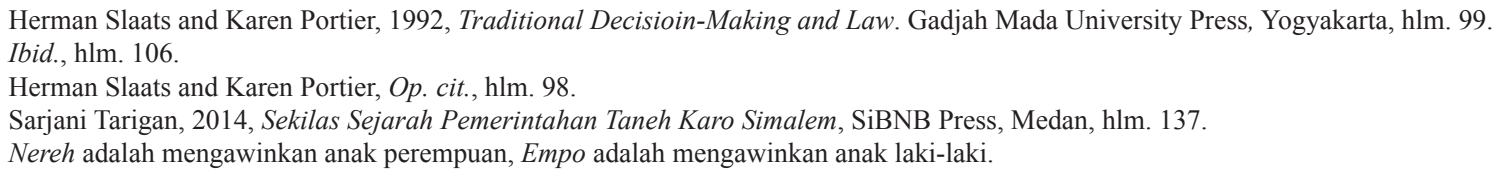


lain tetap memiliki susunan yang sama yaitu adanya kalimbubu, anak beru, dan senina yang diwujudkan dalam konsep sangkep si telu.

Menurut Runtung, dibandingkan dengan forum masyarakat mufakat lainnya maka runggun mempunyai beberapa ciri khas yang penting yaitu: ${ }^{18}$ (1) Runggun itu adalah merupakan musyawarah sangkep si telu secara lengkap, yang berarti para peserta runggun harus dapat mencerminkan wakil-wakil dari masing-masing kelompok kekeluargaan senina, anak beru, dan kalimbubu. Suatu runggun tidak akan dimulai apabila salah satu dari kelompok tersebut belum terwakili. (2) Dalam forum runggun hanya orang-orang yang telah menikah (kawin) saja yang dimintakan pendapatnya.

Proses diadakannya runggun pada umumnya sama adalah dimulai dengan adanya niat/keinginan para pihak untuk membawa permasalahan ke runggun, niat ini kemudian didiskusikan dengan anak beru ${ }^{19}$ terdekat untuk menentukan waktu dan tempat diadakannya runggun serta permasalahan apa yang akan disampaikan di runggun nanti. Setelah diskusi dengan anak beru selesai, maka anak beru kemudian memanggil anak beru lain untuk menginformasikan rencana diadakannya runggun dan berbagi tugas mempersiapkan hal-hal yang diperlukan untuk diadakannya runggun. Setelah persiapan selesai maka anak beru akan mengundang kalimbubu dan senina agar datang untuk runggun.

Sebelum memulai runggun biasanya akan diadakan acara makan terlebih dahulu. Setelah acara makan selesai, kalimbubu akan membuka percakapan dengan bertanya tujuan mereka diundang dalam runggun yang kemudian akan dijawab oleh anak beru yang diwakili oleh anak beru cekoh baka. Baik kalimbubu, anak beru, dan senina akan mempunyai pembicaranya masing-masing. Acara runggun pada umumnya akan dipandu oleh anak beru cekoh baka.

Herman Slaats dan Karen Portier mendeskripsikan tugas anak beru, senina, dan kalimbubu dalam runggun yaitu: (1) Kelompok senina menjelaskan permasalahan yang akan didiskusikan dan menilai masukan yang diajukan untuk menyelesaikan masalah.

(2) Kelompok anak beru berkewajiban memberikan cara-cara penyelesaian masalah.

(3) Kelompok kalimbubu menyetujui masukan yang diajukan kepada mereka. ${ }^{20}$ Kebanyakan runggun untuk menyelesaikan permasalahan akan diadakan pada sore hari. Runggun berdasarkan jenis masalah yang didiskusikan terbagi atas 2 yaitu: Pertama, Runggun yang membicarakan masalah bukan sengketa dapat berupa runggun untuk membicarakan berbagai persiapan pelaksanaan pesta adat perkawinan (erdemu bayu), masuk rumah baru (mengket rumah), menabalkan nama anak yang baru lahir (erbahan gelar), memutuskan tanggal pelaksanaan pesta tahunan (kerja tahun), membicarakan berbagai pembangunan dan pemeliharaan sarana dan prasarana desa dan lain-lain. Kedua, Runggun yang membicarakan penyelesaian sengketa adalah runggun yang membicarakan penyelesaian sengketa yang terjadi dalam masyarakat baik sengketa keluarga, sengketa antar sesame warga desa, sengketa antar warga desa yang satu dengan warga desa yang lain. ${ }^{21}$

\footnotetext{
Runtung, 2002, Keberhasilan dan Kegagalan Penyelesaian Sengketa Alternatif : Studi Mengenai Masyarakat Perkotaan Batak Karo di Kabanjahe dan Brastagi, Disertasi, Program Pascasarjana Universitas Sumatera Utara, Medan, hlm. 182.

19 Masyarakat Karo mempunyai tingkatan anak beru yaitu: anak beru tua kuta/kesain, anak beru tua jabu, anak beru cekoh baka, anak beru jabu, anak beru cekoh baka tutup, anak beru jabu, anak beru niampu, dan anak beru singukuri.

20 Herman Slaats and Karen Portier, Op. cit., hlm. 52.

21 Runtung, Op. cit., , hlm. 184.
} 


\section{b. Penyelesaian Sengketa Melalui Perumah Begu. \\ Perumah Begu adalah upaya penye-} lesaian sengketa dimana $b e g u^{22}$ akan dipanggil melalui ritual tertentu guna menyelesaikan sengketa yang terjadi. Umumnya roh orang yang telah meninggal dunia ini dianggap sebagai orang yang bijaksana serta mempunyai hubungan yang dekat dengan pihak yang bersengketa sehingga mengetahui letak permasalahan para pihak. Perumah begu bagi orang yang telah meninggal dunia dilakukan pada malam pertama setelah mayat dikebumikan. Medium perantara antara roh orang mati dengan pihak yang bersengketa adalah Guru Sibaso. ${ }^{23}$ Guru Sibaso pada umumnya terdiri dari seorang wanita atau beberapa wanita yang memiliki kemampuan untuk berhubungan dengan roh orang yang telah meninggal.

Dalam hal mengundang Guru Sibaso untuk datang ke rumah terlebih dahulu dipersiapkan Belo Penahanen yang berisi: (1) Belo Sempedi (satu ikat daun sirih); (2) Timbako sepangpang (satu gulungan tembakau kering); (3) Gambir (gambir); (4) Pinang (buah pinang); (5) Kapur ${ }^{24}$ (kapur) Para pihakyang bersengketa akan berkumpul di rumah dimana akan dilaksanakan ritual perumah begu, disertai dengan sembuyak ${ }^{25}$, anak beru, senina, dan kalimbubu. Dalam ritual perumah begu, kesenian dan tari berperan untuk mengundang roh tersebut datang.

Pada saat melakukan ritual perumah begu, maka roh orang mati tadi akan memasuki tubuh Guru Sibaso (bagi orang karo, keadaan ini disebut dengan selok (possessed)), pada tahap ini Guru Sibaso akan meminjamkan tubuhnya untuk dimasuki roh orang mati, dalam hal ini Guru Sibaso akan menjadi spirit medium/shaman antara roh dengan orang yang hidup. Berikutnya roh orang mati tadi akan berbicara kepada pihak yang bersengketa melalui Guru Sibaso guna menyelesaikan sengketa mereka. Selama prosesi ritual, Guru Sibaso akan memainkan dua peran penting, yaitu sebagai 'master of ceremony' atau pemimpin utama ritual dan juga berperan sebagai 'story teller in dramatical ritual' Guru Sibaso sebagai penceritera kembali kisah hidup dari orang yang baru meninggal. ${ }^{26}$ Dilihat dari fungsinya Guru Sibaso dalam masyarakat adat dipandang sebagai konsultan (biak penungkunen) dimana warga akan meminta penjelasan mengenai nasehat-nasehat atas permasalahan mereka. Nasehat terutama sangat dibutuhkan dalam kasus konflik antar warga atau antar kerabat. Jika kasus terjadi dalam lingkup kerabat dekat, Guru Sibaso akan menyarankan diadakannya perumah dibata dan disusul dengan perumah begu pada malam harinya dengan hanya melibatkan kerabat dekat yang bersengketa. ${ }^{27}$ Dengan selesainya ritual perumah begu, maka Guru Sibaso tersebut harus diantarkan sampai ke rumahnya.

Sifat masyarakat adat Karo yang religio-magis ditunjukkan dalam ritual perumah begu. Beberapa ritual yang melibatkan Guru Sibaso yang cenderung dilakukan oleh masyarakat Karo antara lain perumah begu ${ }^{28}$, raleng tendi $i^{29}$, erpangir $k u$ la $u^{30}$, ataupun

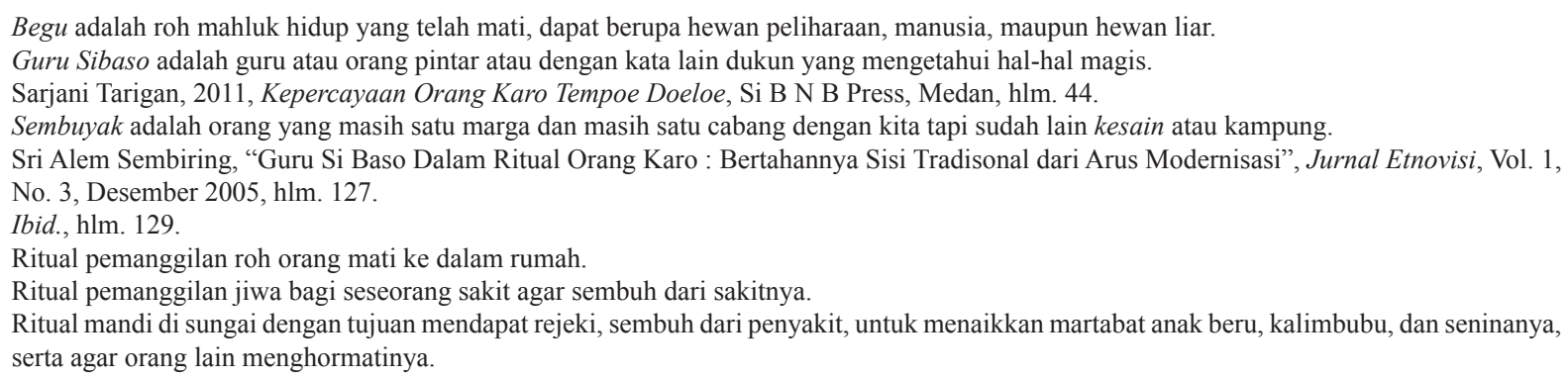


perumah dibata (perumah jenujung) ${ }^{31}$.

\section{c. Penyelesaian Sengketa Melalui Pengadilan Negeri.}

Pengadilan Negeri merupakan lembaga formal yang paling dekat dengan masyarakat dalam struktur hukum formal untuk menegakkan keadilan. Keadaan ini menempatkan Pengadilan Negeri Kabanjahe dalam posisi yang harus tanggap atas nilainilai yang berkembang di masyarakat Karo. Keadilan yang dijanjikan oleh lembaga pengadilan ini terbuka untuk segala golongan masyarakat (equality of justice). Masyarakat Karo umumnya memperlakukan pengadilan sebagai lembaga terakhir untuk menyelesaikan sengketa mereka, terutama dalam hal waris. Menurut masyarakat Karo adalah hal yang sangat memalukan apabila permasalahan harta warisan dibawa ke pengadilan. Hal ini dikarenakan dengan mengajukan sengketanya ke pengadilan maka mereka akan menyerahkan penyelesaiannya kepada pihak ketiga yang menurut mereka tidak akan mengetahui akar permasalahan dari sengketa mereka, namun dikarenakan runggun dianggap tidak lagi dapat memberikan jalan keluar permasalahan, maka diajukanlah sengketa tadi ke pengadilan.

Produk hakim dari hasil pemeriksaan perkara di persidangan ada 3 (tiga) bentuk yaitu: (a) Putusan suatu pernyataan yang oleh hakim sebagai pejabat yang diberi wewenang itu, diucapkan di persidangan dan bertujuan mengakhiri atau menyelesaikan suatu perkara atau sengketa antara para pihak. ${ }^{32}$ (b) Penetapan atau putusan declaratoir yaitu suatu putusan yang bersifat menetapkan, menerangkan saja. ${ }^{33}$ (c) Akta Perdamaian adalah surat penyelesaian perselisihan yang bersifat final and binding. ${ }^{34}$ Dariketiga produk hakim di atas, hanya penetapan yang berasal dari permohonan. Penetapan merupakan pernyataan hakim yang dituangkan dalam bentuk tertulis dan diucapkan oleh hakim dalam sidang terbuka untuk umum sebagai hasil dari pemeriksaan perkara permohonan (voluntair). Oleh karena ruang lingkup permasalahan dibatasi hanya mengenai sengketa, maka penetapan tidak akan diulas lebih lanjut.

Dengan masuknya perkara ke pengadilan maka baik senina, kalimbubu, anak beru, maupun penetua adat tidak dapat lagi campur tangan dalam menyelesaikan masalah. Menurut Perma No. 1 Tahun 2008 yang telah diubah dengan Perma No. 1 Tahun 2016 Pasal 1 butir(2) dan(3), yang bisa menjadi mediator dalam penyelesaian sengketa di pengadilan adalah hakim karir dan hakim non karir. Hakim non karir ini harus memenuhi persyaratan mempunyai sertifikat mediator yang dikeluarkan oleh Mahkamah Agung, oleh karena itu, baik senina, kalimbubu, anak beru, maupun penetua adat tidak dapat lagi camur tangan dalam menyelesaikan masalah. Namun dengan dimasukkannya mediasi ke pengadilan, kesempatan berdamai bagi para pihak sengketa terbuka lagi walaupun bentuk perdamaian yang ditawarkan oleh pihak pengadilan tidak mengikutsertakan runggun di dalamnya.

\section{d. Penyelesaian Sengketa di Pengadilan \\ Berbentuk Putusan}

Dalam menyelesaikan sengketa waris tanah adat di PN Kabanjahe bentuk penyelesaian sengketa yang sering dijumpai adalah putusan. Menurut Sudikno Mertokusumo, putusan hakim adalah suatu pernyataan yang oleh hakim, sebagai pejabat yang diberi wewenang itu, diucapkan di persidangan dan

Ritual pemanggilan roh penjaga badan seseorang.

Sudikno Mertokusumo, 1993, Hukum Acara Perdata Indonesia, Liberty, Yogyakarta, hlm. 174.

Retnowulan Sutantio dan Iskandar Oeripkartawinata, 2002, Hukum Acara Perdata Dalam Teori dan Praktek, Mandar Maju, Bandung, hlm. 10.

H.P Panggabean, Op. cit., hlm. 209. 
bertujuan mengakhiri atau menyelesaikan suatu perkara atau sengketa antara para pihak. ${ }^{35}$ Sesuai dengan ketentuan Pasal 189 Rbg dan Pasal 178 HIR yaitu:(1) Hakim dalam waktu bermusyawarah karena jabatannya, harus mencukupkan alasan-alasan Hukum, yang mungkin tidak dikemukakan oleh kedua belah pihak; (2) Ia wajib mengadili segala bagian gugatan. (3) Ia dilarang menjatuhkan keputusan atas perkara yang tidak digugat, atau meluluskan lebih dari apa yang digugat.

Berdasarkan Pasal 189 Rbg dan Pasal 178 HIR, apabila pemeriksaan perkara selesai, Majelis hakim karena jabatannya melakukan musyawarah untuk mengambil putusan yang akan diajukan. Proses pemeriksaan dianggap selesai apabila telah menempuh tahap jawaban dari tergugat sesuai dari Pasal 121 HIR, Pasal $113 \mathrm{Rv}$, yang dibarengi dengan replik dari penggugat berdasarkan Pasal $115 \mathrm{Rv}$, maupun duplik dari tergugat, dan dilanjutkan dengan proses tahap pembuktian dan konklusi. Jika semua tahapan ini telah tuntas diselesaikan, Majelis menyatakan pemeriksaan ditutup dan proses selanjutnya adalah menjatuhkan atau pengucapan putusan.

Ada berbagai jenis putusan hakim dalam pengadilan, antara lain: ${ }^{36}$ Pertama, Putusan akhir adalah putusan yang mengakhiri pemeriksaan di persidangan, baik telah melalui semua tahapan pemeriksaan maupun yang tidak/belum menempuh semua tahapan pemeriksaan. Macam-macam putusan akhir adalah sebagai berikut: (1) Putusan Declaratoir, putusan yang sifatnya hanya menerangkan, menegaskan suatu keadaan hukum semata, misalnya menerangkan bahwa A adalah ahli waris dari B dan C. (2) Putusan Constitutif, putusan yang sifatnya meniadakan suatu keadaan hukum atau menimbulkan suatu keadaan hukum yang baru, misalnya putusan yang menyatakan seseorang jatuh pailit. (3) Putusan Condemnatoir, putusan yang berisi penghukuman, misalnya pihak tergugat dihukum untuk menyerahkan sebidang tanah berikut bangunan yang ada di atasnya untuk membayar hutangnya. Kedua, Putusan Sela (Putusan interlokutoir) adalah putusan yang dijatuhkan sebelum putusan akhir yang diadakan dengan tujuan untuk memungkinkan atau mempermudah kelanjutan pemeriksaan perkara. Putusan sela selalu tunduk pada putusan akhir karena tidak berdiri sendiri dan akhirnya dipertimbangkan pula pada putusan akhir, hakim tidak terikat pada putusan sela, bahkan hakim dapat mengubahnya sesuai dengan keyakinannya. ${ }^{37}$ Putusan sela tidak dapat dimintakan banding kecuali bersama-sama dengan putusan akhir. Dalam hukum acara dikenal macam putusan sela yaitu: (1) Putusan Preparatuir, putusan persiapan mengenai jalannya pemeriksaan untuk melancarkan segala sesuatu guna mengadakan putusan akhir; (2) Putusan Interlocutoir, putusan yang isinya memerintahkan pembuktian karena putusan ini menyangkut pembuktian maka putusan ini akan mempengaruhi putusan akhir; (3) Putusan Incidental, putusan yang berhubungan dengan insiden yaitu peristiwa yang menghentikan prosedur peradilan biasa. (3) Putusan Provisional, putusan yang menjawab tuntutan provisi yaitu permintaan pihak yang berperkara agar diadakan tindakan pendahulu guna kepentingan salah satu pihak sebelum putusan akhir dijatuhkan.

\section{e. Penyelesaian Sengketa di Pengadilan Berbentuk Mediasi}

Mediasi sengketa waris tanah adat pada PN Kabanjahe adalah mediasi yang

\footnotetext{
Sudikno Mertokusumo, Loc. cit.

R. Subekti, 1989, Hukum Acara Perdata, Binacipta, Bandung, hlm. 129.

Iqbal Albanna, "Putusan Hakim dan Eksekusi", pn-nunukan.go.id, diakses tanggal 7 Maret 2016.
} 
melibatkan mediator dalam pelaksanaannya. Mediasi adalah suatu proses penyelesaian sengketa dimana para pihak yang bersengketa memanfaatkan bantuan pihak ketiga yang independen untuk bertindak sebagai mediator (penengah) dengan menggunakan berbagai prosedur, teknik, dan ketrampilan untuk membantu para pihak dalam menyelesaikan sengketa mereka melalui perundingan.

Proses mediasi dipimpin oleh mediator dan dilaksanakan di ruangan mediasi dengan mempertemukan para pihak yang bersengketa. Mediator menurut Pasal 1 angka (5) Perma No. 1 Tahun 2008 tentang Prosedur Mediasi di Pengadilan adalah pihak yang bersifat netral dan tidak memihak, yang berfungsi membantu para pihak dalam mencari berbagai kemungkinan dalam penyelesaian sengketa. Sebagai pihak ketiga yang netral dan tidak memihak, mediator harus melaksanakan fungsinya berdasarkan kehendak para pihak.

Mediator dalam mediasi di PN Kabanjahe terbagi 2 yaitu: (1) Hakim Mediator Bersertifikat, Mediator Hakim adalah hakim pada pengadilan yang ditunjuk untuk menjadi hakim mediator dan hakim yang telah mendapat pelatihan mediator bersertifikat. Jumlah hakim mediator di PN Kabanjahe ada 3 (tiga) orang. Hakim yang menjadi mediator bukanlah hakim yang menagani perkara yang sedang dimediasikan, tetapi hakim-hakim lainnya di PN Kabanjahe. (2) Mediator Bersertifikat Non-Hakim, Mediator bersertifikat non-hakim adalah mediator bukan hakim yang telah mendapat pelatihan mediator bersertifikat oleh lembaga yang mendapat akreditasi oleh Mahkamah Agung RI.

Mediasi sebagai proses beracara di pengadilan mengikat hakim untuk mewajibkan para pihak melaksanakan mediasi sesuai dengan waktu yang ditentukan. Mengingat pentingnya mediasi dalam proses beracara, maka ketidak hadiran tergugat tidak menghalangi pelaksanaan mediasi. Hakim atau kuasa hukum berkewajiban mendorong para pihak untuk berperan langsung atau aktif dalam proses mediasi. Adanya kewajiban menjalankan mediasi, membuat hakim dapat menunda proses persidangan perkara. Dalam menjalankan mediasi, para pihak bebas memilih mediator yang disediakan oleh pengadilan atau mediator di luar pengadilan. Mediator tidak hanya berperan sebagai fasilitator saja melainkan harus berperan secara langsung dan aktif dalam menyelesaikan sengketa para pihak dan menemukan berbagai kemungkinan untuk penyelesaian sengketanya.

Menurut Pasal 4 PERMA No. 1 Tahun 2008, ruang lingkup objek penanganan lembaga mediasi adalah semua sengketa perdata yang diajukan ke pengadilan tingkat pertama kecuali kasus dalam bidang hukum perselisihan hubungan industrial, hukum perlindungan konsumen, serta hukum persaingan usaha. Putusan perdamaian mempunyai kekuatan eksekutorial sebagaimana diuraikan dalam Pasal 1858 KUHPerdata, Pasal 130 HIR/154 RBg yaitu: (a) Pasal 1858 ayat (1) KUHPerdata: segala perdamaian mempunyai di antara pihak suatu kekuatan seperti suatu putusan Hakim dalam tingkat penghabisan. (b) Pasal 130 ayat (2) HIR: Jika perdamaian yang demikian itu dapat dicapai, maka pada waktu sidang diperbuat sebuah akta tentang itu, dalam mana kedua belah pihak dihukumkan akan menepati perjanjian yang diperbuat itu, surat mana akan berkekuatan dan akan dijalankan sebagai putusan yang biasa. (b) Pasal 130 ayat (3) HIR: Putusan yang sedemikian tidak diizinkan banding. ${ }^{38}$ 
Proses mediasi dapat berlangsung 40 (empat puluh) hari sejak mediator dipilih oleh para pihak atau setelah ditunjuk oleh ketua majelis hakim dan dapat diperpanjang 14 (empat belas) hari lagi sesuai dengan kesepakatan para pihak. Selama proses mediasi berlangsung, mediator berkewajiban menyiapkan jadwal mediasi, mendorong para pihak secara langsung berperan dalam proses mediasi, dan bila dianggap perlu dapat melakukan kaukus. Kaukus adalah pertemuan secara terpisah yang dilakukan Mediator dengan salah satu pihak yang berperkara tanpa diketahui lawan. Tujuan kaukus ini untuk membicarakan hal-hal yang bersifat rahasia kepada mediator sehingga dapat menjadi bahan pertimbangan bagi mediator untuk memahami permasalahan dan menemukan penyelesaian sengketa yang dapat diterima para pihak.

Dalam proses mediasi, mediator dapat melibatkan ahli seorang atau lebih untuk memberikan penjelasan atau pertimbangan yang dapat membantu menyelesaikan perbedaan pendapat para pihak. Pelibatan ahli atas dasar persetujuan para pihak dan biaya untuk jasa ahli juga ditanggung oleh para pihak berdasarkan kesepakatan mereka. Akibat hukum dari tidak dipatuhinya keharusan proses mediasi tersebut ditentukan dalam ketentuan Pasal 2 ayat (3) dan ayat (4) PERMA No. 1 Tahun 2008 yang menyatakan sebagai berikut: Pertama, Tidak menempuh prosedur mediasi berdasarkan peraturan ini merupakan pelanggaran terhadap ketentuan Pasal 130 HIR dan atau Pasal 154 RBg yang mengakibatkan putusan batal demi hukum. Kedua, Hakim dalam pertimbangan putusan perkara wajib menyebutkan bahwa perkara yang bersangkutan telah diupayakan perdamaian melalui mediasi dengan menyebutkan nama mediator untuk perkara yang bersangkutan. ${ }^{39}$

Bila para pihak tidak mencapai kesepakatan dalam masa 40 (empat puluh) hari sejak para pihak memilih mediator, maka mediator wajib menyampaikan secara tertulis bahwa proses mediasi telah gagal, dan memberitahukan kegagalan mediasi kepada hakim. Segera setelah menerima pemberitahuan tersebut, maka hakim melanjutkan pemeriksaan perkara sesuai dengan ketentuan hukum acara yang berlaku. Apabila mediasi dinyatakan gagal maka menurut Pasal 19 ayat (1) PERMA No. 1 Tahun 2008 segala pernyataan dan pengakuan para pihak dalam proses mediasi tidak dapat digunakan sebagai alat bukti dalam proses persidangan perkara yang bersangkutan atau perkara lainnya. Hal ini bertujuan agar proses mediasi tidak disalahgunakan oleh pihak yang beritikad tidak baik untuk menjebak lawan dengan berpura-pura ingin berdamai, padahal mereka memiliki niat yang tidak baik, sehingga dengan demikian proses mediasi ini dapat digunakan untuk melindungi pihak yang beritikad tidak baik. ${ }^{40}$

\section{Penutup}

Berdasarkan penjelasan yang sudah disampaikan di atas diketahui bahwa ada 3 cara yang ditempuh oleh masyarakat adat Karo dalam menyelesaikan sengketa waris tanah adatnya antara lain: (1) Penyelesaian sengketa melalui runggun; (2) Penyelesaian sengketa melalui Perumah Begu; (3) Penyelesaian sengketa melalui Pengadilan Negeri. 


\section{DAFTAR PUSTAKA}

\section{A. Buku}

Amriani, Nurnaningsih, 2011, Mediasi Alternatif Penyelesaian Sengketa Perdata di Pengadilan, Raja Grafindo Press, Jakarta.

Hadikusuma, Hilman, 1990, Hukum Perkawinan Adat, Citra Aditya Bakti, Bandung.

Mertokusumo, Sudikno, 1993, Hukum Acara Perdata Indonesia, Liberty, Yogyakarta.

Setiady, Tolib, 2008, Intisari Hukum Adat Indonesia (Dalam Kajian Kepustakaan), Penerbit Alfabeta, Bandung.

Poerwadarminta, W.J.S., 1999, Kamus Umum Bahasa Indonesia, Balai Pustaka, Jakarta.

Wiranata, I Gede A.B., 2005, Hukum Adat Indonesia Perkembangannya dari Masa ke Masa, Citra Aditya Bakti, Bandung.

Samosir, Djamanat, 2013, Hukum Adat Indonesia Eksistensi Dalam Dinamika Perkembangan Hukum di Indonesia, Nuansa Aulia, Bandung. Sarjani Tarigan, 2011, Kepercayaan Orang Karo Tempoe Doeloe, Si B N B Press, Medan 2014, Sekilas Sejarah Pemerintahan Taneh Karo Simalem, SiBNB Press, Medan.

Slaats, Herman and Portier, Karen, 1992, Traditional Decisioin-Making and Law. Gadjah Mada
University Press, Yogyakarta.

Soekanto, Soerjono, 1985, Meninjau Hukum Adat Indonesia, Rajawali, Jakarta.

Subekti, R., 1989, Hukum Acara Perdata, Binacipta, Bandung.

Sutantio, Retnowulan dan Oeripkartawinata, Iskandar, 2002, Hukum Acara Perdata Dalam Teori dan Praktek, Mandar Maju, Bandung.

\section{B. Hasil Penelitian}

Runtung, 2002, Keberhasilan dan Kegagalan Penyelesaian Sengketa Alternatif : Studi Mengenai Masyarakat Perkotaan Batak Karo di Kabanjahe dan Brastagi, Disertasi, Program Pascasarjana Universitas Sumatera Utara, Medan.

\section{Artikel dalam Jurnal}

Sembiring, Sri Alem, “Guru Si Baso Dalam Ritual Orang Karo : Bertahannya Sisi Tradisonal dari Arus Modernisasi", Jurnal Etnovisi, Vol. 1, No. 3, Desember 2005.

\section{Artikel Internet}

Albanna, Iqbal, "Putusan Hakim dan Eksekusi”, pnnunukan.go.id, diakses tanggal 7 Maret 2016. 